PROBLEMS

OF EDUCATION IN THE $21^{\text {st }}$ CENTURY Vol. 79, No. 5, 2021

694

\title{
USING THE COVID-19 PANDEMIC AS A SOCIOSCIENTIFIC ISSUE TO SUPPORT THE SCIENTIFIC HABITS OF MIND
}

\author{
Muammer Çalık \\ Trabzon University, Turkey \\ E-mail: muammer38@hotmail.com
}

The COVID-19 pandemic has affected all people without discriminating any border, country, race, ethnicity and so forth (Arroio, 2020). Thus, it has acted as a new playmaker in recognizing the importance of education and social justice. As stated by Usak et al. (2020), we, as educators, should pay more attention to the development of students' awareness and scientific attitudes. Thus, they are able to think, understand, decide and make an action about any urgent event or "forced" transition, i.e., the pandemic process (Rodgríguez et al., 2021). Unfortunately, the COVID-19 pandemic seems to have generated a climate of fear for scientific advances and mass vaccination as well as regulations on lockdown, socialization, and hygiene.

Given the foregoing features, the COVID-19 pandemic typically involves debate among scientists, politicians, and citizens when decision making about the use of science and regulations (Çalık \& Wiyarsi, 2021). Phrased differently, the COVID-19 pandemic incorporates the related classification features of socio-scientific issues (e.g., holding different key beliefs/views/values, and lack of a scientific consensus) (Çalik \& Coll, 2012). Further, it possesses a contentious dilemma, which is an ill-structured, open-ended, and complex problem. Because it consists of such multiple dimensions as economic, political, technological, scientific, and environmental, it has challenged our memorized content knowledge and regular habits. Therefore, we can recruit it to stimulate the scientific habits of mind (SHOM) suggested by Gauld (1982).

The SHOM is not only a useful way to characterize how scientists think (Gauld, 1982) but also improves the scientific attitude. Gauld (1982, p.110) explains the importance of the SHOM with the following quotation: "No idea, conclusion, decision or solution is accepted just because a particular person makes a claim but is treated skeptically and critically until its soundness can be judged according to the weight of evidence, which is relevant to it." As a matter of fact, some leaders' speeches on the COVID-19 pandemic also indicate why the SHOM is necessary for all. For example, ex-President Donald Trump, who routinely referred to the COVID-19 as "the China virus," "the Wuhan virus" and "Kung Flu," claimed that it had come from a Wuhan lab. But anybody with the SHOM wonders whether there is enough evidence that the China has misled the global community over the COVID-19. Similarly, President Jair Bolsonaro and President Aleksandr Lukashenko omitted the COVID-19 pandemic and rejected strict measures against it. In a similar vein, Prime Minister Boris Johnson showed the fastest government U-turn after infected with the COVID-19. These specific cases reveal that the SHOM helps us ask critical questions before making a decision. Therefore, in this paper, I will illustrate seven components (mistrust of arguments from authority, open-mindedness, skepticism, rationality, objectivity, suspension of belief and curiosity) of the SHOM using the information on the COVID-19 pandemic and key features. 


\section{Mistrust of Arguments from Authority}

Information: Although there is noeffective therapy for the COVID-19, hydroxychloroquine (HCQ) and chloroquine (CQ) have been used for its treatment. But their safety and efficacy remain uncertain. For this reason, authorities have two different ideas: COVID-19

Idea 1: The use of HCQ and CQ is effective at decreasing the mortality rate during the

Idea 2: The use of HCQ and CQ is ineffective at reducing the mortality rate during the COVID-19.

Key features: Two different ideas in which experts have fallen into disagreement; a comparison or evaluation of their trustworthiness (Çalik \& Coll, 2012, p. 1921).

Given this information and the key features, we can ask provocative questions (e.g., which of these ideas is trustable for you? Please explain your reason(s); please compare and evaluate these ideas with each other in terms of their trustworthiness) to stimulate the "mistrust of arguments from authority" component.

\section{Open-mindedness}

Information: During the COVID-19 pandemic, such vaccines as Sinovac, PfizerBioNTech are used. Of these vaccines, Sinovac, which is an inactive vaccine, employs traditional procedures. The others exploit a new approach called mRNA Technologies.

Key features: Existence of a problem to stimulate; an issue or problem is not simply overlooked or dismissed; being willing to consider the possibility that something is true; changing his/her ideas in the light of the evidence (Çalik \& Coll, 2012, p. 1921)

Given this information and the key features, we can ask the following questions to activate the "open-mindedness" component:

- If possible, which of the mass vaccines do you prefer? Please defend your reason(s)

- If there is more evidence on new mRNA technologies, are you willing to consider the possibility of getting a new shot, e.g., Pfizer-BioNTech?

- Do you change your ideas in the light of the evidence?

\section{Skepticism}

Information: A study by Buchholz (2020) showed that respondents selected from different countries had skeptical views of the COVID-19 restrictions (see Figure 1).

\section{Figure 1}

The Results of a Survey on the COVID-19 Restrictions

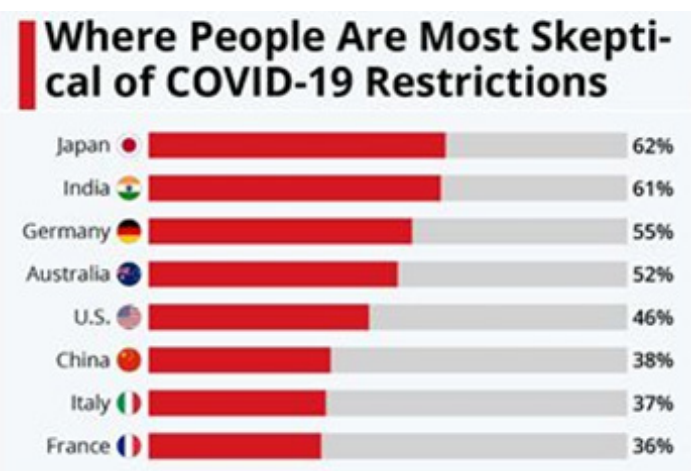


PROBLEMS

OF EDUCATION

IN THE $21^{\text {st }}$ CENTURY

Vol. 79 , No. 5,202

Key features: A provisional approach to claims to clarify the extent to which it might be true (real); involving critically questioning the claim(s) thereby, the certainty though scientific or logical observation is aimed to acquire (Çalik \& Coll, 2012, p. 1921).

Given Figure 1 and key features, we can use provocative questions (e.g., which of the countries shows a provisional approach to the travel restrictions during the COVID-19? Do you think they ask critically questions about the COVID-19 restrictions? Are the COVID-19 restrictions enough to overcome the virus?) to arouse the "skepticism" component.

\section{Rationality}

Information: To treat the COVID-19, scientific community has developed several vaccines, whose types, efficacy levels, storage conditions and costs are varied (see Table 1).

Table 1

A Summary of Several Vaccines Used for Treating the COVID-19

\begin{tabular}{lccccc}
\hline Vaccines & Type & Country & $\begin{array}{c}\text { Efficacy in } \\
\text { preventing } \\
\text { COVID-19 }(\%)\end{array}$ & Storage conditions & Cost (USD) \\
\hline $\begin{array}{l}\text { Oxford / Astra } \\
\text { Zeneca }\end{array}$ & Viral vector & UK & 70 & 6 months at $+4^{\circ} \mathrm{C}$ & 3 \\
\hline Sinovac & Inactivated & China & 50 & 3 years at $+2-8^{\circ} \mathrm{C}$ & 60 \\
\hline Biontech / Pfizer & m-RNA & Germany & 95 & 6 months at $-70^{\circ} \mathrm{C}$ & 20 \\
\hline Moderna & m-RNA & USA & 95 & 6 months at $-20^{\circ} \mathrm{C}$ & 25 \\
\hline Sputnik V & Viral vector & Russia & 91 & 6 months at $+4^{\circ} \mathrm{C}$ & 10 \\
\hline
\end{tabular}

Note: Adapted from Terry, 2021

Key features: A need for good reasons and logical argument by which to link ideas, evidence, and reasons together in an appropriate way; a need to revise ideas or beliefs in the light of evidence and argument (Çalik \& Coll, 2012, p. 1921).

Given Table 1 and key features, we can exploit the subsequent questions to trigger the 'rationality' component: (a) If you were a minister of health, which vaccine would you select for your country in regard to Table 1? Please explain your reason(s). (b) What good reasons and logical arguments convince you about the type of vaccine?

\section{Objectivity}

Information: Clinical trials for the COVID-19 vaccines consist of several phases and cover different research designs with volunteers from various countries (see Table 2). 
Table 2

A Summary of Clinical Trials for the COVID-19 Vaccine

\begin{tabular}{lllll}
\hline Candidate & Phase & Study design & Volunteer & Country \\
\hline Moderna mRNA-1273 & 3 & Double-blind randomized & 30000 & USA \\
\hline Sinovac CoronaVac & 3 & Double-blind randomized & 13,060 & Brazil \\
\hline Oxford ChAdOx1-S & 3 & Double-blind randomized & 40,051 & USA, Chile, Peru \\
\hline BioNTech BNT162 & $2 / 3$ & $\begin{array}{l}\text { Dose-finding, double-blind } \\
\text { randomized }\end{array}$ & 43,998 & $\begin{array}{l}\text { USA, Argentina, } \\
\text { Brazil, others }\end{array}$ \\
\hline Novavax NVX-CoV2373 & 2 & Single-blind randomized & 4,400 & South Africa \\
\hline KBP-COVID-19 & $1 / 2$ & $\begin{array}{l}\text { Observer-blind, dose-finding } \\
\text { randomized }\end{array}$ & 180 & Not Provided \\
\hline
\end{tabular}

Note: Adopted from Haidere et al., 2021, p. 4-5

Key features: Evidence, bias and scrutiny (Çalik \& Coll, 2012, p. 1921-1922)

Given Table 2 and the key features, we can ask the following questions to stimulate the 'objectivity' component: (a) Why do the COVID-19 studies follow double-blinded or singleblinded randomization? (b) Why do they carry out their studies in different countries? (c) Why do they follow different phases (pre-clinical, phase I, phase II, phase III) before licensing? (d) How do these procedures reflect features of the objectivity? (e) What happens if any clinical research is published without peer review or double-blinded review?

\section{Suspension of Belief}

Information: Aljazeera published the news about AstraZeneca's COVID-19 vaccine to report which countries have stopped using this vaccine. An excerpt from the news is as follows:

More than a dozen countries, mostly in Europe, have suspended the use of AstraZeneca's COVID-19 vaccine over fears the shot may have caused some recipients to develop blood clots. Sweden and Latvia on Tuesday became the latest nations to halt the rollout, following moves by Germany, Italy, France, Spain, Denmark, Norway, and The Netherlands, among others.

The World Health Organization (WHO) is meeting on Tuesday to review the available safety data on the vaccine, although it has repeatedly expressed confidence in its safety; WHO chief Tedros Adhanom Ghebreyesus has said there was no evidence of a link so far.

The European Medicines Agency (EMA) reiterated its stance on Tuesday, that the vaccine is safe, and its benefits outweigh any risks as coronavirus infections and deaths continue. The regulator will release results of its investigation into incidents of bleeding, blood clots and low platelet counts in recipients on Thursday (Adopted from Aljazeera, 2021).

Key features: A procedure of holding in abeyance; if there is insufficient evidence to make a decision, one should not rush in too quickly in support of some particular idea or theory (Çalik \& Coll, 2012, p. 1922)

Given the news and key features, we can utilize the following questions to activate the "suspension of belief" component: (a) Why did these countries suspend the use of AstraZeneca's COVID-19 vaccine? (b) After research on any link between blood clots and AstraZeneca's COVID-19 vaccine, do you think to get a shot for this vaccine? Please defend your reason(s) (c) Even though the WHO has said that there is no evidence of a link between the blood clot and vaccine, why do people hesitate to make a decision? 
PROBLEMS

OF EDUCATION

IN THE $21^{\text {st }}$ CENTURY Vol. 79, No. 5, 2021

698

\section{Curiosity}

Information: Handwashing with soap kills the COVID-19 in that soap molecules disrupt its fatty layer. Hence, this process not only inactives its function but also prevents spread of the virus.

Key features: A desire to learn; a need to arouse inquisitiveness for exploration and discovery (Çalik \& Coll, 2012, p. 1922)

Given this information and the key features, we can ask the following questions to pose the 'curiosity' component: (a) what science concepts do this information include? (b) How do soap molecules dissolve the fatty layer? (c) How can you explain this process via intermolecular forces?

Even though the foregoing tasks/activities have not been tested yet, this paper illustrates how to use the COVID-19 pandemic as a socio-scientific issue to support the SHOM. Hence, relevant tasks/activities promote the participants to improve their scientific attitudes and enable them to capture how scientists produce scientific knowledge. Further, the participants are able to learn that scientific knowledge construction requires strong argumentation, reasoning and communication skills as well as the experiments, observations and evidence (Bağ \& Çalık, 2017). Therefore, let's conduct much more research on the integration of the SHOM into science learning and share the results with the stakeholders.

\section{References}

Aljazeera (2021). Which countries have stopped using AstraZeneca's COVID vaccine? https://www. aljazeera.com/news/2021/3/15/which-countries-have-halted-use-of-astrazenecas-covid-vaccine

Arroio, A. (2020). The value of education in the context of Covid-19 pandemic. Problems of Education in the $21^{\text {sl }}$ Century, 78(3), 309-313. https://doi.org/10.33225/pec/20.78.309

Bağ, H., \& Çalık, M. (2017). A thematic review of argumentation studies at the K-8 level. Education and Science, 42(190), 281-303. http://dx.doi.org/10.15390/EB.2017.6845

Buchholz, K. (2020). Where people are most skeptical of COVID-19 restrictions? https:/www.statista. com/chart/21242/share-of-people-saying-covid-19-restrictions-wont-work-selected-countries/

Çalik, M., \& Coll, R. (2012). Investigating socio-scientific issues via scientific habits of mind: Development and validation of the scientific habits of mind survey. International Journal of Science Education, 34(12), 1909-1930. https://doi.org/10.1080/09500693.2012.685197

Çalık, M., \& Wiyarsi, A. (2021). A systematic review of the research papers on chemistry-focused socioscientific issues. Journal of Baltic Science Education, 20(3), 360-372. https://doi.org/10.33225/ jbse/21.20.360

Gauld, C. F. (1982). The scientific attitude and science education: A critical reappraisal. Science Education, 66, 109-121. https://doi.org/10.1002/sce.3730660113

Haidere, M. F., Ratan, Z. A., Nowroz, S., Zaman, S. B., Jung, Y. J., Hosseinzadeh, H., \& Cho, J. Y. (2021). COVID-19 vaccine: Critical questions with complicated answers. Biomolecules \& Therapeutics, 29(1), 1-10. https://doi.org/10.4062/biomolther.2020.178

Rodgríguez, C. L., Mula-Falcón, J., Segovia, J. D., \& Cruz-González, C. (2021). The effects of covid-19 on science education: A thematic review of international research. Journal of Turkish Science Education, Covid-19 Special Issue, 26-45. https://dx.doi.org/10.36681/tused.2021.70

Terry, M. (2021). Updated comparing COVID-19 vaccines: Timelines, types and prices. https://www. biospace.com/article/comparing-covid-19-vaccines-pfizer-biontech-moderna-astrazenecaoxford-j-and-j-russia-s-sputnik-v/

Usak, M., Masalimova, R. A., Cherdymova, I. E., \& Shaidullina, R. A. (2020). New playmaker in science education: Covid-19. Journal of Baltic Science Education, 19(2), 180-185. https://doi. org/10.33225/jbse/20.19.180 
Muammer ÇALIK. Using the Covid-19 pandemic as a socioscientific issue to support the scientific habits of mind

PROBLEMS

OF EDUCATION

IN THE $21^{\text {st }}$ CENTURY

Vol. 79, No. 5, 2021

Received: September 25, 2021

Accepted: October 03, 2021

699

Cite as: Calik, M. (2021). Using the Covid-19 pandemic as a socioscientific issue to support the scientific habits of mind. Problems of Education in the $21^{\text {st }}$ Century, 79(5), 694-699. https://doi.org/10.33225/pec/21.79.694

Muammer Çalik

PhD, Professor of Chemistry Education, Department of Elementary Teacher Education, Fatih Faculty of Education, Trabzon University, 61300, Trabzon, Turkey.

E-mail: muammer38@hotmail.com

Website: https://www.researchgate.net/profile/Muammer_Calik

ORCID ID: https://orcid.org/0000-0001-8323-8783 